\title{
Seroprevalence and social determinants of varicella in Turkey
}

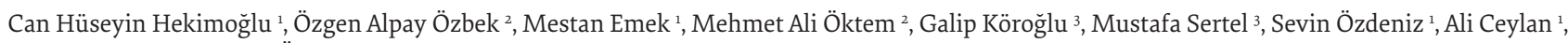
Ayla Açikgöz ${ }^{1}$ and Belgin Ünal ${ }^{1}$

'Department of Public Health, Faculty of Medicine, Dokuz Eylul University, Izmir, Turkey (Correspondence to: C.H. Hekimoğlu: drchh@hotmail.com). ${ }^{2}$ Department of Medical Microbiology, Faculty of Medicine, Dokuz Eylul University, Izmir, Turkey. ${ }^{3}$ Manisa Directorate of Public Health, Manisa, Turkey.

\begin{abstract}
Background: In Turkey, varicella vaccine was introduced into routine childhood immunization in 2013, with a single dose administered to children aged 12 months. However, there is limited information on the morbidity (incidence and seroprevalence), mortality and burden of disease of varicella in the overall Turkish population.

Aim: To determine varicella seroprevalence and its social determinants in Manisa Province, Turkey in children aged $>2$ years before single-dose varicella vaccination was introduced in 2013.

Methods: The presence of anti varicella-zoster virus IgG antibodies was determined using enzyme-linked immunosorbent assay in serum samples collected from 1250 participants.

Results: The overall seroprevalence was $92.8 \%$ and the seroprevalence was $>90 \%$ among all age groups except $2-9$ years $(55.7 \%)$. Seroprevalence was significantly associated with family size, annual per capita equivalent income, number of people per room and education level. After adjusting by age, only education level remained significantly associated with seroprevalence, reflecting the early age effect.

Conclusion: High seroprevalance depends on natural exposure to the infectious agent itself and is not associated with social determinants. High vaccine coverage should be maintained for effective varicella control and switching to a 2-dose schedule may also be considered to reduce the number and size of outbreaks in the Turkish population.
\end{abstract}

Keywords: seroprevalence, social factors, Turkey, vaccination, varicella

Citation: Hekimoğlu CH; Ozbek ÖA; Emek M; Öktem MA; Köroğlu G; Sertel M; et al. Seroprevalence and social determinants of varicella in Turkey. East Mediterr Health J. 2018;24(3):295-301. https://doi.org/10.26719/2018.24.3.295

Received: 03/05/16; accepted: 13/02/17

Copyright @ World Health Organization (WHO) 2018. Some rights reserved. This work is available under the CC BY-NC-SA 3.0 IGO license (https:// creativecommons.org/licenses/by-nc-sa/3.o/igo).

\section{Introduction}

Varicella or chickenpox is distributed worldwide and is an acute highly contagious infectious disease caused by varicella-zoster virus (VZV), which has no animal reservoir $(1,2)$. While varicella occurs predominantly in childhood in temperate climate regions, it is also a disease of people aged 20-25 years in subtropical and tropical climate regions, with a lower overall incidence (2-4). Although varicella is often mild and self-limiting in healthy children, some complications such as secondary bacterial infection of the skin, viral or bacterial pneumonia, encephalitis and cerebellitis can be life threatening especially in adolescents, adults and immunosuppressive individuals $(2,5-7)$.

In 1998, the World Health Organization (WHO) recommended routine vaccination for countries where varicella is an important public health and socioeconomic problem, if high vaccine coverage could be provided and it were economically viable (8). In some countries such as the United States of America (USA), Greece, Republic of Korea, Canada and Saudi Arabia, varicella is included in the routine childhood immunization programme. In some countries such as England and Belgium, the vaccine is administered to seronegative individuals after childhood and at high risk for varicella $(9,10)$. In developing countries, as the burden of other diseases is higher than that of varicella, introduction of varicella vaccination into the national immunization programme is not a high priority. For these countries, a targeted vaccination strategy may be an option $(2,8)$.

In Turkey, varicella vaccine was introduced into the routine childhood immunization programme in 2013, with a single dose administered to children aged 12 months. However, there is limited information on the morbidity (incidence and seroprevalence), mortality and disease burden of varicella in the overall Turkish population (11-22). Furthermore, varicella was only included in the notifiable diseases list in Turkey in 2011. Therefore, we aimed to determine varicella seroprevalence in the population aged $>2$ years in Manisa Province and to examine some of the social determinants for varicella seroprevalence. This reflects the population before the introduction of varicella vaccination into the routine childhood immunization programme in Turkey in 2013.

\section{Methods}

This cross-sectional study was conducted as part of the population survey titled "Determination of the seroprevalence of some vaccine preventable diseases in Manisa, 2014". Manisa is located in Western Anatolia and has a population of $\sim 1.3$ million. In terms of 
socioeconomic development, Manisa was ranked 23rd among 81 provinces of Turkey in 2011 (23).

The sampling frame consisted of all individuals aged $>2$ years who were registered under Manisa Province Family Medicine Information System in October 2013 $(\mathrm{n}=1317$ 917). The minimum sample size required was calculated as 1337 people within a $95 \%$ confidence level using the EpiInfo computer programme (Centers for Disease Control and Prevention, Atlanta, USA), assuming anticipated seronegativity of $2.0 \%$ and absolute precision of $0.75 \%$. The estimated sample size was then inflated by $30 \%$ to reach 1740 to overcome nonresponse bias. The sample was selected using a simple random sampling method from the Manisa Province Family Medicine Information System. Individuals who were selected for the study were invited to the family health centres by physicians or midwives. Data were collected from participants in family health centres between 18 March and 22 June 2014.

Ten interviewers were trained and standardized for data collection. Written informed consent was obtained from the participants, and questionnaires were completed by the interviewers during face-to-face interviews. Serum samples were collected in the family health centres, transported to a centre in Manisa at $4-8^{\circ} \mathrm{C}$ and stored at $-20^{\circ} \mathrm{C}$. Once weekly, samples were sent to the laboratory at $-20^{\circ} \mathrm{C}$ to be stored at $-80^{\circ} \mathrm{C}$ until they were tested. The study protocol was approved by the Dokuz Eylul University Clinical Research Ethics Board.

Among 1740 people who were sampled, 168 could not be reached in their place of residence, 312 refused to participate in the study and 10 participants' blood samples were excluded from the analyses due to haemolysis or insufficient quantity. We analysed data from 1250 people (response rate: $71.8 \%$ ).

The dependent variable of the study was varicella seropositivity. The independent variables were gender, age groups, area of residence, family size, number of people per room, annual per capita equivalent income, education level and employment status. The presence of specific varicella antibodies in serum samples was determined using Euroimmun (Medizinische Labordiagnostika AG, Lübeck, Germany) anti-VZV IgG ELISA test. Test results with $<80 \mathrm{IU} / \mathrm{ml}$ were considered as negative and those with $\geq 110 \mathrm{IU} / \mathrm{ml}$ were considered as positive. The results between these values were considered as uncertain. For the analysis, uncertain and negative results were interpreted as seronegative and positive results were interpreted as seropositive.

Categorical variables were summarized with count, percentage and $95 \%$ confidence interval (CI) and compared using the $\chi^{2}$ test in univariate analysis. Continuous variables were summarized with median, minimum and maximum values. Crude and age-adjusted odds ratios and $95 \%$ CIs for social determinants of varicella seropositivity were calculated using logistic regression analysis. All statistical analyses were performed using SPSS version 15.0 (SPSS Inc., Chicago, IL, USA).

\section{Results}

The study group was $52.1 \%$ female and $47.9 \%$ male, with a median age of $36(2-89)$ years. Varicella seroprevalence was 92.8\% (95\% CI: $91.2-94.1 \%$ ) among all the participants. The seroprevalence changed between 92.6 and $100.0 \%$ in children aged $>9$ years but it was 37.1 and $61.9 \%$ for the 2-4- and 5-9-year age groups, respectively ( $\mathrm{P}<$ 0.001) (Figure 1). There was no significant difference in seroprevalence according to gender $(P=0.37)$, area of residence $(P=0.57)$ and employment status $(P=0.83)$ (Table 1). Seroprevalence was significantly increased in participants whose family size was $\leq 4(\mathrm{OR}=1.75,95 \%$ CI: 1.12-2.72); participants who had $\leq 1$ person per room $(\mathrm{OR}=2.32,95 \% \mathrm{CI}: 1.49-3.62)$; and participants in the 3rd and 4th quartiles of annual per capita equivalent income (OR $=1.94,95 \%$ CI: $1.03-3.65$ and OR $=2.21$, $95 \%$ CI: 1.14-4.27). These associations disappeared after age adjustment. There was also a significant difference in varicella seroprevalence according to education level. Seroprevalence was $>95 \%$ for participants at all education levels, apart from those who were not of school age (38.1\%) or attending primary school $(74.2 \%)(\mathrm{P}<0.001)$. After adjusting by age, the only significant variable for varicella seroprevalence was education level. Age-adjusted OR for varicella seroprevalence was 0.16 (95\% Cl: 0.03-0.92) in participants who were not of school age.

\section{Discussion}

Varicella seroprevalence was $92.8 \%$ among people aged > 2 years in Manisa in 2014. The study population did not receive varicella vaccine in the national immunization programme since it was not introduced for children aged 12 months until 2013. Therefore, our findings reflect the seroepidemiology of varicella before the vaccine was introduced as part of the national immunization programme. The seroprevalence was $>90 \%$ among all age groups except 2-9 years, which was $55.7 \%$. This suggests that varicella exists in the population and almost $90 \%$ of the population contract the virus by age 10 years.

In most temperate climates, $>90 \%$ of the population become seropositive for varicella before adolescence and the incidence ranges from 13 to 16/100o per year (2). In a comparative seroepidemiology study in 11 countries in Europe between 1996 and 2003, varicella seroprevalence was $>90 \%$ in children aged 10-14 years, except in Italy (81.7\%) and England and Wales (89.7\%) (24). There have been several previous epidemiological studies on varicella in Turkey that included different age groups (11-22). In 9 provinces of Turkey in 2002, the seroprevalence was $77.8 \%$ in the population aged $<30$ years and this increased with age and reached $85 \%$ at 10 years (11). In eastern regions of the country the seroprevalence was $78 \%$ in people aged $<30$ years in 2004 and $69 \%$ in those aged $1-16$ years in $2006(12,13)$. Varicella seroprevalence among school children aged 7-15 years residing in Manisa was $61.6 \%$ in 2009-2010 (14). In a 2010 study of people aged 1-80 years in Izmir, which is a neighbouring province of Manisa, varicella seroprevalence was $71.5 \%$ (15). The 


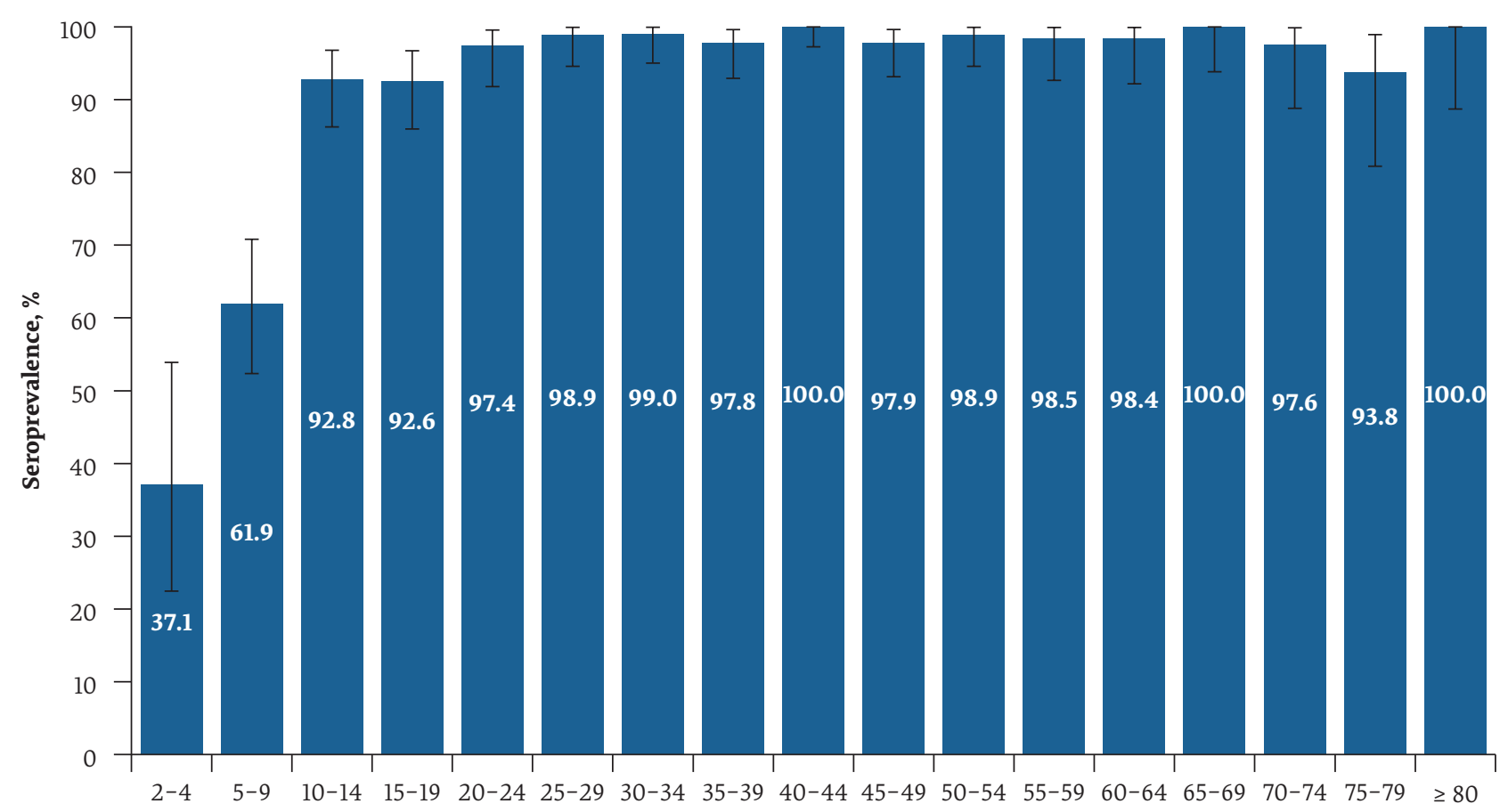

Age groups

$P<0.001$

Figure 1 Varicella seroprevalance and 95\% confidence intervals by age groups, Manisa Province, Turkey, 2014.

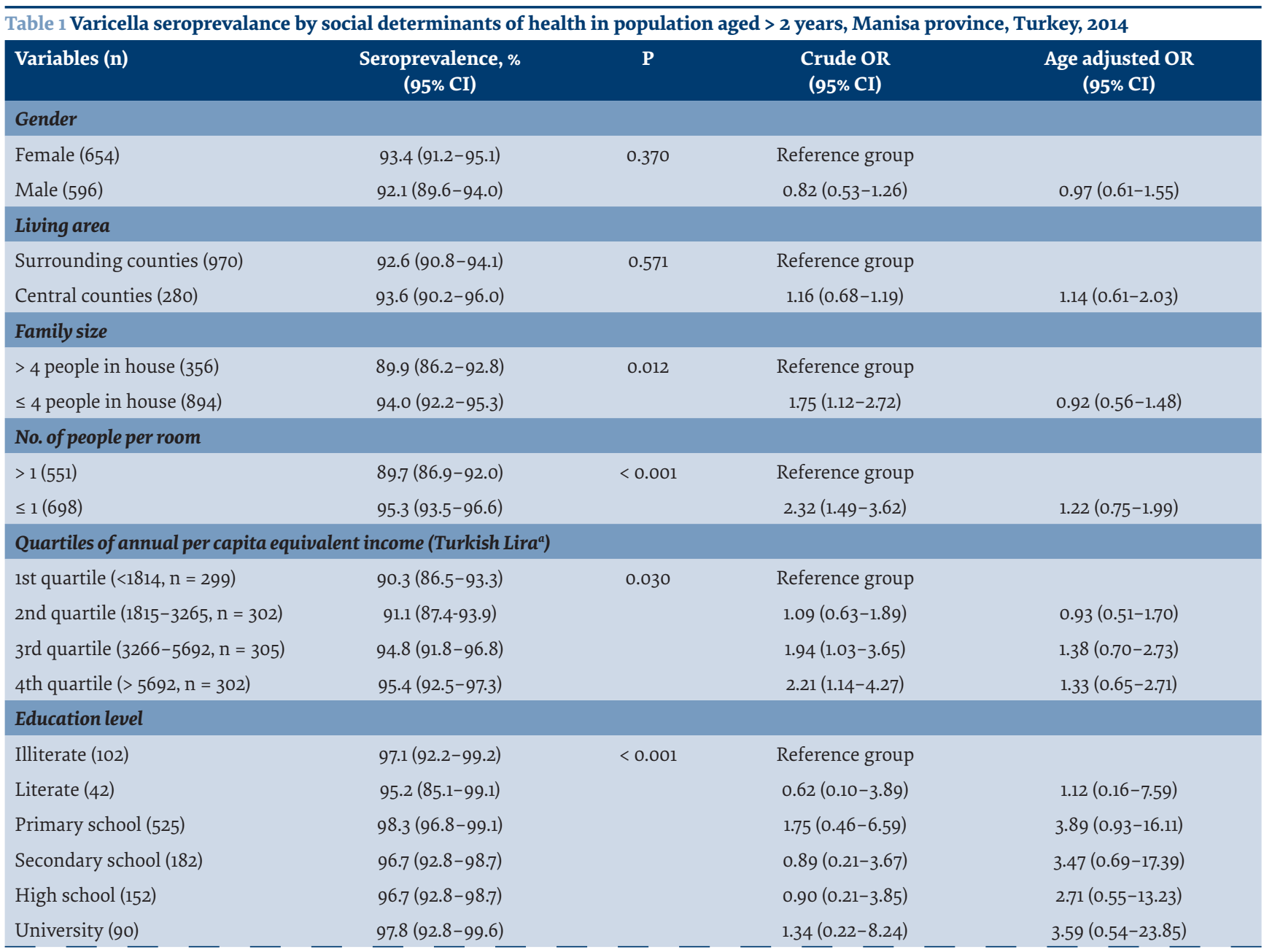




\begin{tabular}{|c|c|c|c|c|}
\hline Variables (n) & $\begin{array}{c}\text { Seroprevalence, \% } \\
(95 \% \mathrm{CI})\end{array}$ & $\mathbf{P}$ & $\begin{array}{c}\text { Crude OR } \\
\text { (95\% CI) }\end{array}$ & $\begin{array}{c}\text { Age adjusted OR } \\
(95 \% \mathrm{CI})\end{array}$ \\
\hline Attending primary school (93) & $74.2(64.5-82.3)$ & & $0.08(0.02-0.30)$ & $0.64(0.12-3.41)$ \\
\hline Not of school age (63) & $38.1(26.7-50.5)$ & & $0.01(0.0-0.06)$ & $0.16(0.03-0.92)$ \\
\hline \multicolumn{5}{|l|}{ Employment status (> 18 years) } \\
\hline Employed (539) & $98.5(97.2-99.3)$ & 0.826 & Reference group & \\
\hline Unemployed (68) & $98.5(92.9-99.3)$ & & $1.00(0.12-8.19)$ & $1.05(0.12-8.68)$ \\
\hline Out of workforce/student (347) & $98.0(96.0-99.1)$ & & $0.73(0.26-8.19)$ & $0.73(0.26-2.04)$ \\
\hline
\end{tabular}

${ }^{a} 1$ Turkish lira was equal to average 2.14 US dollars between March and June 2014.

seroprevalence increased to $80.0 \%$ in the $10-14$-year age group and to $88.3 \%$ among young adults. In another study in Izmir in 2009-2010, the seroprevalence was $94.3 \%$ in the population aged $>15$ years (16). Seroprevalence was reported to be $91.8 \%$ among Turkish immigrants in the Amsterdam adult population in 2004 and $96 \%$ among the 21-25-year age group in the Turkish population of Cyprus in 2007 (17-25). According to these results, which are consistent with the current study, varicella is common in the Turkish population and the seroprevalence increases with age, with a peak incidence in childhood.

It is known that the most important risk factors associated with severity and mortality of varicella are older age and a compromised immune system. Varicella case fatality rates are about 1 per 100000 people in children and the risk of death is 4 times higher in infants than in children and 23-29 times higher in adults. Average crude varicella mortality rates range from 0.3 to 0.5 per million people annually. It is estimated that varicella leads to 4.2 million severe complications annually that require hospitalization and 4200 deaths globally (26). In developed countries, overall case fatality rates are 2-4 per 100 ooo cases compared to $1-3$ per 1000 cases for measles $(2,26)$. Despite the routine use of measles and pertussis vaccination, the age-standardized death rate per 100000 cases in 2010 was lower for varicella (0.1) than measles (1.7) and pertussis (1.1) (26). According to WHO recommendations, varicella should be considered an important public health problem that requires routine vaccination (8). A few studies in Turkey have evaluated the financial burden and mortality of varicella in children and adults $(18,19)$. In a multicentre study from 2008 to 2010 that included 824 children aged $<15$ years hospitalized for varicella, total median length of hospital stay was 6 days and $0.36 \%$ of the children died of complications. Approximately $26 \%$ of these varicella-related hospitalized children had an immunosuppressive condition or chronic underlying disease and death was 5 times higher in such children than in previously healthy children (18). This study was hospital based, and deaths from varicella were possibly overestimated. Therefore, varicella case fatality rate is expected to be $<0.36 \%$ in the population.

Varicella is one of the most contagious diseases. The basic reproduction number (Ro) estimates for varicella ranged between 3.3 and 16.9 in serum banks that were collected between 1996 and 2003 in 11 European countries, and herd immunity thresholds varied from 70 to $94 \%$ (24). This means that if the varicella-susceptible proportion in a population is over this threshold, an outbreak is not expected to occur in that population (24-27). However, we currently have no Ro and herd immunity threshold estimation for the Turkish population. WHO recommends that resources should be sufficient to ensure reaching and sustaining varicella vaccine coverage for $\geq 80 \%$ of the population. If vaccine coverage remains $<80 \%$ over the long term, it is expected to shift varicella infection to older age groups in some settings, and this may increase morbidity and mortality despite a reduction in the total number of cases. The number of doses administered is determined by the goal of the vaccination programme. If the goal of the programme is to reduce mortality and severe morbidity from varicella, 1 dose is sufficient. A 2-dose schedule increases vaccine effectiveness. Therefore, 2 doses are recommended in countries where the goal is to reduce the number of cases and outbreaks as well as mortality and severe morbidity (26).

We found that varicella seroprevalence was not associated with the social factors that were explored, except for education level, which actually reflects the early age effect. Our expectation was to demonstrate higher exposure to VZV and higher varicella seroprevalence in disadvantaged groups, for example, people with lower education, lower income per capita or crowded housing. However, only the group who was not of school age or at primary school had low varicella seroprevalence, suggesting that exposure to varicella increased with schooling. Some studies have reported that living in urban areas, living in a large family ( $\geq 4$ people) and children with more siblings are factors associated with higher varicella seroprevalence. Many studies have found no gender difference for varicella seroprevalence $(2,3,16$, 17, 28-30). Consistent with the current study, varicella seroprevalence was not associated with household size, income, occupation and education in a population-based study in Izmir in 2009-2010 (16).

The current study had some strengths. First, the study group was randomly sampled from a general population and had a high response rate, hence it was representative of all age groups > 2 years in Manisa Province. The study reflected the epidemiology of varicella before the introduction of routine varicella vaccination, which can 
provide invaluable baseline information for evaluating the impact of the vaccination programme. Although some socioeconomic and primary healthcare quality variations existed between the provinces, the findings may give some indicators about the whole country since our study group was a random sample from Manisa.

Our study also had some limitations. First, vaccination histories were not taken from the participants, and some may have received varicella vaccine in private clinics before the vaccination programme started. However the number of such people should not be a large proportion of the study participants. Second, the overall response rate was $72 \%$ and we evaluated the age and gender structure of responders and nonresponders. There was no significant difference between the 2 groups by age but there were more female than male participants in the study. However, there was no significant gender difference in seroprevalence; therefore it can be considered that the overall seroprevalence was not greatly affected by this limitation. Third, since there were fewer participants in the subcategories according to social determinant variables, the statistical power may have been lower to determine the difference in seroprevalence between those subcategories. For example, the literate group had only 42 participants and the unemployed group 68 .

In conclusion, since the study included age groups before starting routine varicella vaccination in Turkey, the observed varicella seroprevalence depended on natural exposure to VZV and was not associated with social determinants. For successful varicella control by routine vaccination programme, vaccine coverage and effectiveness, burden of varicella and change in seroepidemiology in Turkey should carefully be followed up. High vaccine coverage should be targeted and maintained. Otherwise, varicella outbreaks affecting older age groups, with more severe clinical features, are inevitable. To reduce the number and size of varicella outbreaks, as well as severe morbidity and mortality, switching to a 2-dose vaccination schedule may also be considered for the national immunization programme in Turkey.

\section{Acknowledgements}

We thank the nurses in family health centres for collecting serum samples from the participants and the doctors in community and family health centres for their support for the inclusion of participants in Manisa. We also thank the students of the Department of Social Services of Celal Bayar University for data collection and Dokuz Eylül University Scientific Research Projects Unit for financial support. We also thank Yucel Demiral, Sema Alp Cavus, Ziya Tay, Gonca Atasoylu, Sanem Baykal, Ozgur Sekreter, Yasin Saglam, Duygu Islek, Nur Demirpence, Umran Kolukirik and Hilal Gorgel for their contribution to the study.

Funding: This study was financially supported Dokuz Eylul University Scientific Research Projects Unit (grant number: 2014.KB.SAG.019).

Competing interests: None declared.

\section{Séroprévalence et déterminants sociaux de la varicelle en Turquie}

\section{Résumé}

Contexte : En Turquie, le vaccin contre la varicelle a été introduit dans le programme de vaccination systématique des enfants en 2013, avec une seule dose administrée aux enfants de 12 mois. Toutefois, les informations concernant la morbidité (incidence et séroprévalence), la mortalité et la charge de morbidité de la varicelle dans l'ensemble de la population turque sont limitées.

Objectif : Déterminer la séroprévalence de la varicelle et ses déterminants sociaux dans la province de Manisa (Turquie) chez des enfants de plus de deux ans avant l'introduction de la vaccination en une seule dose en 2013.

Méthodes : La présence d'anticorps IgG dirigés contre le virus varicelle-zona (VZV) a été déterminée à l'aide de la méthode immuno-enzymatique (ELISA) sur des échantillons de sérum collectés auprès de 1250 participants.

Résultats : La séroprévalence globale de la varicelle était de $92,8 \%$ et la séroprévalence était supérieure à $90 \%$ au sein de tous les groupes d'âge, excepté chez les 2-9 ans $(55,7 \%)$. La séroprévalence de la varicelle était associée à la taille de la famille, au revenu annuel équivalent par habitant, au nombre d'individus par classe et au niveau d'éducation $(p<0,05)$. Après un ajustement par l'âge, seul le niveau d'éducation restait significativement associé à la séroprévalence de la varicelle $(p<0,05)$, reflétant l'importance d'un jeune âge.

Conclusion: Une forte séroprévalence dépend de l'exposition naturelle à l'agent infectieux et n'est pas associée aux déterminants sociaux. Une couverture vaccinale élevée devrait être maintenue si l'on veut que la lutte contre la varicelle soit efficace et le passage à un schéma vaccinal à deux doses afin de réduire le nombre et l'ampleur des flambées de varicelle dans la population turque. 


\section{الانتشار المصلي والمحددات الاجتماعية للحُحماق في تركيا}

جن حكم أولو، أوزقن أوزبك، ميستان إمك، محمد أكتم، غالب كوروجلو، مصطفى سيرتل، سيفن أزديناز، علي سيلان، آيلا أكيكجوز، بيلجن

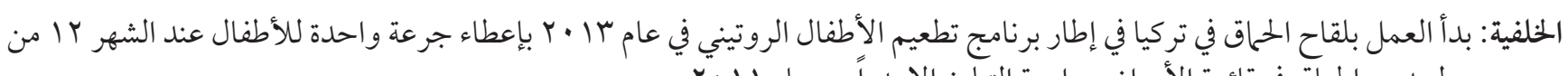

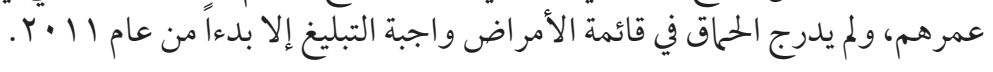

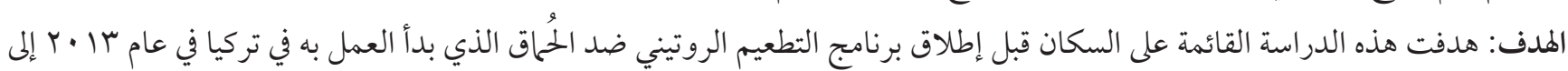

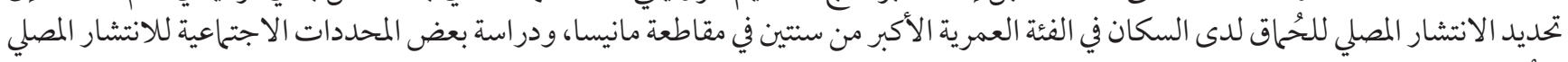
للنحُماق.

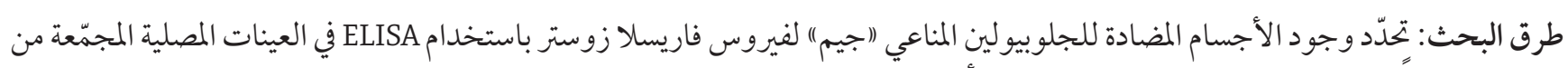

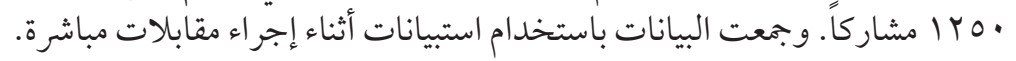

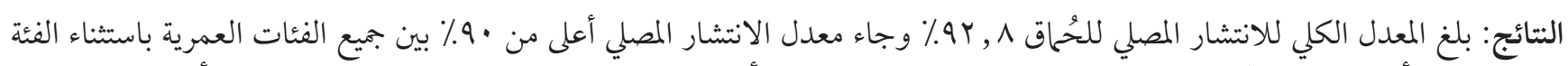

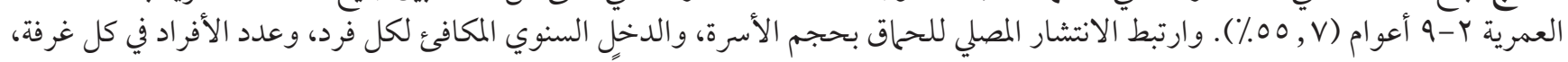

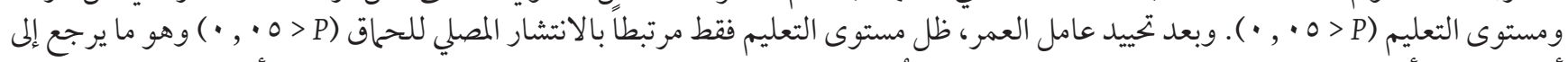

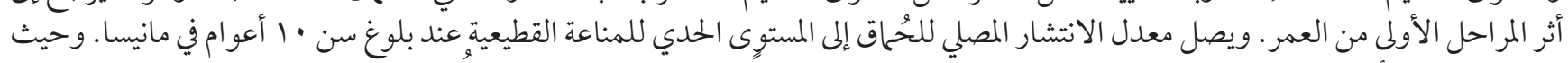

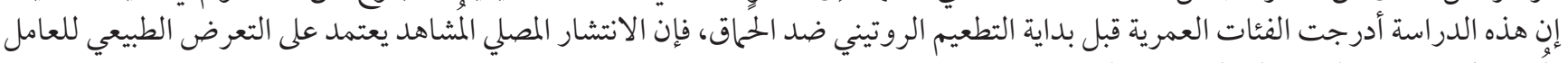
المعدي في حد ذاته ولا يرتبط بالمحددات الإجتماعية.

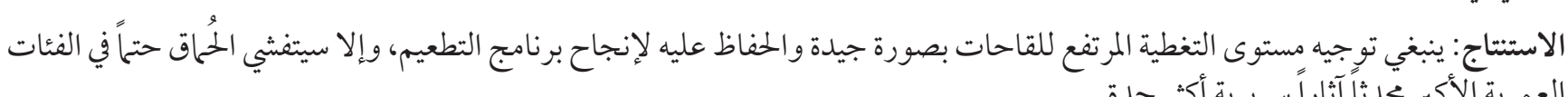
العمرية الأكبر محدثاً آثاراً سريرية أكثر حدة.

\section{References}

1. Myers MG, Stanberry LR. Varicella-zoster virus. In: Behrman RE, Kliegman RM, Jenson HB, editors. Nelson textbook of pediatrics. Philadelphia: W.B. Saunders; 2000:973-7.

2. Heininger U, Seward JF. Varicella. Lancet. 2006 Oct 14;368(9544):1365-76. https://doi.org/10.1016/So140-6736(06)69561-5 PMID:17046469

3. Lolekha S, Tanthiphabha W, Sornchai P, Kosuwan P, Sutra S, Warachit B, et al. Effect of climatic factors and population density on varicella zoster virus epidemiology within a tropical country. Am J Trop Med Hyg. 2001 Mar;64(3):131-6. https://doi.org/10.4269/ ajtmh.2001.64.131 PMID:11442207

4. Wharton M. The epidemiology of varicella-zoster virus infections. Infect Dis Clin North Am. 1996 Sep;10(3):571-81. https://doi. org/10.1016/S0891-5520(05)70313-5 PMID:8856352

5. Choo PW, Donahue JG, Manson JE, Platt R. The epidemiology of varicella and its complications. J Infect Dis. 1995 Sep;172(3):70612. https://doi.org/10.1093/infdis/172.3.706 PMID:7658062

6. Enders G, Bolley I, Miller E, Cradock-Watson J, Ridehalgh M. Consequences of varicella and herpes zoster in pregnancy: prospective study of 1739 cases. Lancet. 1994 Jun 18;343(8912):1548-51. https://doi.org/10.1016/So140-6736(94)92943-2 PMID:7802767

7. Takahashi M, Gershon AA, Seward JF. Varicella vaccine. In: Plotkin SA, Orenstein WA, Offit PA, editors. Vaccines. Philadelphia: Elsevier;2004:783-823.

8. Varicella vaccines. WHO position paper. Wkly Epidemiol Rec. 1998 Aug 7;73(32):241-8. PMID:9715106

9. Bonanni P, Breuer J, Gershon A, Gershon M, Hryniewicz W, Papaevangelou V, et al. Varicella vaccination in Europe - taking the practical approach. BMC Med. 200905 28;7(1):26. https://doi.org/10.1186/1741-7015-7-26 PMID:19476611

10. Sengupta N, Booy R, Schmitt HJ, Peltola H, Van-Damme P, Schumacher RF, et al. Varicella vaccination in Europe: are we ready for a universal childhood programme? Eur J Pediatr. 2008 Jan;167(1):47-55. https://doi.org/10.1007/s00431-007-0424-0 PMID:17334784

11. Kanra G, Tezcan S, Badur S; Turkish National Study Team. Varicella seroprevalence in a random sample of the Turkish population. Vaccine. 2002 Jan 31;20(9-10):1425-8. https://doi.org/10.1016/S0264-410X(01)00459-5 PMID:11818162

12. Alp H, Altinkaynak S, Ertekin V, Kiliçaslan B, Giiraksin A. Seroepidemiology of varicella-zoster virus infection in a cosmopolitan city (Erzurum) in the eastern Turkey. Health Policy. 2005 Apr;72(1):119-24. https://doi.org/10.1016/j.healthpol.2004.03.008 PMID:15760704

13. Gürgöze MK, Yilmaz E, Gödekmerdan A, Akça Z, Doğan Y, Akarsu S, et al. Seroprevalence of mumps, varicella and rubella antibodies in children 1-16 years of age in eastern Turkey. Turk J Pediatr. 2006 Jul-Sep;48(3):185-8. PMID:17172059

14. Kose U, Ozguven AA, Ecemis T, Akçalı S, Lagarlı T, Onag A. Prevalence of chickenpox in children aged 7-15 years residing in Manisa. Ege J Med. 2011;50(3):187-91. 
15. Koturoglu G, Kurugol Z, Turkoglu E. Seroepidemiology of varicella-zoster virus and reliability of varicella history in Turkish children, adolescents and adults. Paediatr Perinat Epidemiol. 2011 Jul;25(4):388-93. https://doi.org/10.1111/j.1365-3016.2010.01180.x PMID:21649681

16. Kose S, Mandiracioglu A, Senger SS, Ulu Y, Cavdar G, Gol B, et al. Seroprevalence of varicella-zoster virus in the prevaccine era: a population-based study in Izmir, Turkey. J Infect Public Health. 2013 Apr;6(2):115-9. https://doi.org/10.1016/j.jiph.2012.10.003 PMID:23537824

17. Kurugol Z, Koturoglu G, Aksit S, Ozacar T. Varicella seroprevalence in Turkish population in Cyprus. Acta Paediatr. 2007 Jun;96(6):861-3. https://doi.org/10.1111/j.1651-2227.2007.00289.x PMID:17465984

18. Dinleyici EC, Kurugol Z, Turel O, Hatipoglu N, Devrim I, Agin H, et al.; VARICOMP Study Group. The epidemiology and economic impact of varicella-related hospitalizations in Turkey from 2008 to 2010: a nationwide survey during the pre-vaccine era (VARICOMP study). Eur J Pediatr. 2012 May;171(5):817-25. https://doi.org/10.1007/soo431-011-1650-z PMID:22170238

19. Ozdemir H, Candir MO, Karbuz A, Belet N, Tapisiz A, Ciftçi E, et al. Chickenpox complications, incidence and financial burden in previously healthy children and those with an underlying disease in Ankara in the pre-vaccination period. Turk J Pediatr. 2011 Nov-Dec;53(6):614-25. PMID:22389983

20. Savaş S, Dallar Y, Arikan I, Onde U. [Varicella-zoster virus seroprevalence in children between o-15 years old]. Mikrobiyol Bul. 2004 Jan-Apr;38(1-2):69-75 (in Turkish). PMID:15293904

21. Dilli D, Dallar Y, Onde, U. Dogan F. Yagci. [Measles, rubella, mumps, and varicella seroprevalence among adolescents]. Cocuk Dergisi. 2008;8(3):172-8 (in Turkish) https://www.journalagent.com/cocuk/pdfs/CD_8_3_172_178.pdf.

22. Ozkan S, Maral I, Ilhan F, Aycan S, Cirak MY, Beyazova U, et al. Varicella zoster seroprevalence in children less than 5 years old. J Trop Pediatr. 2005 Jun;51(3):141-4. https://doi.org/10.1093/tropej/fmh102 PMID:15831668

23. The Ministry of Development of the Turkish Republic. [The socio-economic developmental ranking of provinces and regions (SEGE-2011)] (in Turkish) (http://www.kalkinma.gov.tr/Lists/Yaynlar/Attachments/548/SEGE-2011.pdf, accessed 5 March 2018).

24. Nardone A, de Ory F, Carton M, Cohen D, van Damme P, Davidkin I, et al. The comparative sero-epidemiology of varicella zoster virus in 11 countries in the European region. Vaccine. 2007 Nov 7;25(45):7866-72. https://doi.org/10.1016/j.vaccine.2007.07.036 PMID:17919788

25. van Rijckevorsel GG, Damen M, Sonder GJ, van der Loeff MF, van den Hoek A. Seroprevalence of varicella-zoster virus and predictors for seronegativity in the Amsterdam adult population. BMC Infect Dis. 201206 21;12(1):140. https://doi.org/10.1186/14712334-12-140 PMID:22721551

26. Varicella and herpes zoster vaccines: WHO position paper, June 2014. Wkly Epidemiol Rec. 2014 Jun 20;89(25):265-87. PMID:24983077

27. Nardone A, de Ory F, Carton M, Cohen D, van Damme P, Davidkin I, et al. The comparative sero-epidemiology of varicella zoster virus in 11 countries in the European region. Vaccine. 2007 Nov 7;25(45):7866-72. https://doi.org/10.1016/j.vaccine.2007.07.036 PMID:17919788

28. Halloran ME, Struchiner CJ, Longini IM Jr. Study designs for evaluating different efficacy and effectiveness aspects of vaccines. Am J Epidemiol. 1997 Nov 15;146(10):789-803. https://doi.org/10.1093/oxfordjournals.aje.a009196 PMID:9384199

29. Silhol R, Alvarez FP, Arena C, Amoros JP, Flahault A, Hanslik T, et al. Micro and macro population effects in disease transmission: the case of varicella. Epidemiol Infect. 2010 Apr;138(4):482-90. https://doi.org/10.1017/So950268809990896 PMID:19796448

30. Heininger U, Braun-Fahrländer C, Desgrandchamps D, Glaus J, Grize L, Wutzler P, et al.; SCARPOL Team. Seroprevalence of varicella-zoster virus immunoglobulin $\mathrm{G}$ antibodies in Swiss adolescents and risk factor analysis for seronegativity. Pediatr Infect Dis J. 2001 Aug;20(8):775-8. https://doi.org/10.1097/00006454-200108000-00011 PMID:11734740 